ELORE (ISSN 1456-3010), vol. $18-1 / 2011$.

Julkaisija: Suomen Kansantietouden Tutkijain Seura ry. [http://www.elore.fi/arkisto/__11/kirjat_hytonen2.pdf]

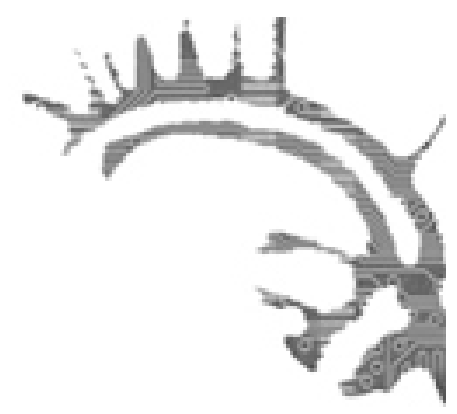

KIRJA-ARVIO

\title{
KULTTUURITUOTANNON KIEMUROISSA
}

GRAHN, MAARIT \& HÄYRYNEN, MAUNU 2009: Kulttuurituotanto: kebyleset, käytäntö ja prosessit. Helsinki: SKS. 326 sivua.

\section{Elina Hytönen}

Suomalaisen Kirjallisuuden Seuran ja Turun yliopiston Kulttuurituotannon ja maisematutkimuksen laitoksen julkaiseman artikkelikokoelman lähtökohtana on luoda katsaus yhteiskunnan toiminta-alueeseen, jota kutsutaan kulttuurituotannoksi. Kirja pyrkii hahmottelemaan, mitä kulttuurituotanto sisältää, ja mitä se jättää ulkopuolelleen. Samanaikaisesti teos pyrkii vahvistamaan käsitystä kulttuurituotannon markkinakytkennöistä sekä monisärmäisyydestä. Kirjassa on yhteensä kuusitoista artikkelia, jotka on jaettu neljään osaan: "Kulttuurituotannon kehykset", "Kulttuuriperintöä tuottamassa", "Kulttuurituotanto ja paikka" sekä "Kulttuurituotanto ja digitaalinen yhteisöllisyys".

\section{KUltTUURIA POLITIIKASTA KIRJALLISUUTEEN}

Kirjan ensimmäinen, kulttuurituotannon kehyksiä käsittelevä osa koostuu neljästä artikkelista. Näistä ensimmäinen, Simo Häyrysen kirjoittama teksti, tarkastelee sitä, millä tavoin kulttuuripolitiikka, eli julkisen vallan toimeenpanema sääntely, liittyy kulttuurituotantoon. Hän tarkastelee osuvasti kulttuuripolitiikkaa sekä erottelukoneena että yhteen kutojana. Häyrynen määrittelee kulttuuripolitiikan tehtäväksi erilaisten kulttuuristen ilmiöiden tunnistamisen sekä julkisen vallan suhtautumisen näihin ilmiöihin. Artikkeli käsittelee myös suomalaisen kulttuurituotannon ja -politiikan ongelmia ja haasteita. Seuraava, Kari Ilmosen kirjoitus, pohtii Suomessa tapahtuvaa aluekehittämistä kulttuurisen käänteen käsitteen avulla. Olennaista kulttuurisen käänteen aiheuttamassa kehityksessä on ollut kulttuuripolitiikassa tapahtunut muutos kohti kulttuurin taloudellisen käytettävyyden korostamista. Ilmosen artikkelin keskeisenä ajatuksena on, että kulttuurin ja taiteen alueellisia toimintaedellytyksiä ja vaikutuksia 
arvioitaessa tulisi mahdollisuuksien mukaan huomioida myös niin sanotut omalakiset emergentit kehityskulut.

Katriina Siivosen kulttuurista kestävyyttä käsittelevä artikkeli näkee kulttuurin dynaamisena prosessina, jatkuvasti muuttuvana virtana. Keskeistä hänen tarkastelulleen on ajatus kulttuurisista tihentymistä, jotka nykypäivän yhteiskunnassa ovat liitoksissa globaaliin vuorovaikutusprosessiin. Siivonen pyrkii nostamaan artikkelissaan esille kysymyksen siitä, mikä kaikki on kulttuurisesti kestävän kehityksen nimissä varjeltavaa kulttuuria. Risto Turusen artikkeli on kirjan ensimmäisen osan helpoimmin lähestyttävä teksti, ja se käsittelee kirjatuotannon räjähdysmäistä kasvua 1990-luvun lopun ja 2000-luvun aikana. Kirjallisuudella on Turusen mukaan ollut oma erityisasemansa suomalaisessa kulttuurituotannossa, ja kustantamoiden tavoitteet tässä kulttuurinalassa ovat tasapainoilleet niin sivistyksellisen ja kasvattavan lähestymistavan kuin täysin kaupallistenkin lähtökohtien välillä. Turunen tarkastelee muun muassa kirjallisuuden taustalla vaikuttavaa kulttuurista muutosta ja tarjoaa näkökulmaa myös kirjallisuuden uusiin trendeihin kuten äänikirjoihin ja pokkareihin.

\section{KULTTUURIPERINTÖÄ TARKASTELEMASSA}

Artikkelikokoelman toisen kulttuuriperintöä käsittelevän osan aloittaa Maarit Grahnin kirjoittama artikkeli, joka tarkastelee Noormarkun ruukkia kulttuuriperintökohteena ja sitä, miten ruukki on mukana paikallisuutta ja kulttuuriperintöä uudentavissa prosesseissa. Kulttuuriperinnön Grahn määrittelee koostuvan sekä aineellisista että aineettomista menneisyyden jäljistä. Nämä jäljet on tunnistettu todisteiksi ihmisen toiminnasta, ja niitä tuotetaan aina uudelleen ja uudelleen vastaamaan eri aikakausien lähtökohtia. Grahnin mukaan kulttuuriperintöä voidaan pitää tietynlaisten valintojen tuloksena, ja sitä käytetään myös vahvistamaan tietyn yhteisön tai ryhmän identiteettiä ja kulttuuria. Anna Sivula tarkastelee vanhaa portugalilaista Coimbran yliopistoa osana kulttuuriperintöprosessia, jonka keskiössä on yliopiston aineeton kulttuuriperintö. Prosessissa on olennaista menneisyydestä mielekkäänä pidetyn historian valikoiminen. Kyse on siis historiakulttuurin tuottamisesta, jota Sivula pitää osana nykykulttuuria.

Outi Tuomi-Nikula taas tarkastelee itäsaksalaisten kartanonomistajien paluumuuttoa takaisin DDR:n aikoinaan takavarikoimille tiluksille yhden kartanon tarjoaman esimerkin kautta. Yhteistä eri aatelisperheiden tarinoille on Tuomi-Nikulan mukaan aina uudestaan kerrottu "suuri kertomus", jossa kerrataan suvun pitkää historiaa samalla, kun uudet kartanon omistajat korostavat maailmansotaa edeltävän ajan tarinoissa kartanonherrojen ja heidän alustalaistensa välisten suhteiden ongelmattomuutta. Muistelut sisältävät sekä aktiivista että tietoista unohtamista.

\section{Paikka, paikallisuus ja kulttuurituotanto}

Kirjan kolmannen osion aloittaa Katriina Petrisalon artikkeli, joka käsittelee lähimatkailua, lyhytlomia sekä kotiseudun käsitettä kulttuurituotannon näkökulmasta. Keskeisenä ajatuksena artikkelissa on työn perässä muuttaneiden uudenlaisten ryhmittymien uu- 
dessa elinympäristössään tekemä lähimatkailu. Maahan- tai maassamuuttajille ominaista on se, että he voivat rakentaa omaa identiteettiään laajemman kulttuurisen identifikaation kautta sitoutumatta maantieteellisiin tai hallinnollisiin rajoihin. Tässä prosessissa matkailua voidaan pitää yhä merkittävämpänä väylänä kulttuuriseen sopeutumiseen. Petrisalon artikkelia seuraa Sami Louekarin teksti, jossa käsitellään maisemaa kulttuurituotantona. Artikkeli tarkastelee kuntien kotisivujen sisältämien maisemakuvien ja mielikuvien kautta tapahtuvaa paikkaidentiteetin tuottamista. Louekari määrittelee maiseman yksilön subjektiiviseksi kokemukseksi ja luomukseksi, jonka kanssa operoivat kuitenkin myös erilaiset viranomaiset ja jota voidaan tarkastella tietynlaisena kulttuurituotantona. Maisema voidaan siis myös tuotteistaa ja kaupallistaa, mutta sen kautta rakennetaan myös identiteettiä ja yhtenäisyyden tunnetta.

Laura Puolamäen ja Eeva Raiken yhteisartikkeli tarkastelee sitä, miten ympäristökasvatuksella voidaan edistää kulttuuriympäristöjen säilymistä. Kulttuuriympäristökasvatuksessa on kirjoittajien mukaan kyse sekä kulttuurin näkökulmasta, ympäristönsuojelusta että ympäristön arvottamisesta. Olennaista lähestymistavassa on ajatus siitä, ettei ympäristö säily itsestään, vaan se tulee säilyttää. Säilyttämiseen pyritään vaikuttamaan juuri ympäristökasvatuksella ja pyrkimällä luomaan omakohtainen suhde suojelun kohteeseen. Elisa El Harounyn artikkeli taas tarkastelee sitä, miten vanhojen puukaupunginosien rakennussuojelu, asukkaiden arvostukset ja arki joutuvat törmäyslinjalle keskenään. El Harouny pohtii tekemiensä haastatteluiden pohjalta, miten Raahen ja Porvoon puukaupunginosien tulevaisuus voitaisiin turvata menettämättä niiden asumisviihtyvyyttä. Artikkeli osoittaa, että muuttuvien asumistarpeiden huomioimisen tulisi olla osa kaupunkien historiaa ja kulttuurista kehitystä.

Kolmannen osan päättää Petja Aarnipuun artikkeli museoista kansallisena kulttuurituotantona. Esimerkkinä hän käyttää Turun linnaa ja sen tuotteistamista, sekä tarkastelee sitä, miten museotyö tuottaa historiakulttuuria ja luo menneisyyskuvia. Olennaista tuotteistamisen prosessia tarkasteltaessa on katsoa, mitä menneisyydestä valitaan, miten se esitetään ja millaisessa prosessissa nämä valinnat tapahtuvat. Aarnipuun mielenkiintoinen väite on, että museoympäristön tärkeimpänä tuotteena on pidettävä ajan tajua.

\section{DigitaAlisen KUlTTUURITUOTANNON TUTKIMINEN}

Kirjan neljäs ja viimeinen osa käsittelee digitaalisen kulttuurin tuotantoa kolmen varsin erityyppisen artikkelin kautta. Petri Saarikosken teksti käsittelee Turun yliopiston digitaalisen kulttuurin oppiaineessa toteutettua yhteisöpelihanketta, Jubana-herttuan Aikakapseli-peliä. Tarkastelun taustalla on huomio erilaisten satunnaispelaajien määrän lisääntymisestä sekä pelaajien keski-iän nousemisesta. Artikkeli linjaa pyrkimyksekseen pohtia sitä, miten erilaisten digitaalisten pelien käytöllä voitaisiin vahvistaa esimerkiksi pelaajien paikallisidentiteettiä.

Pauliina Tuomi käsittelee artikkelissaan yleisön vuorovaikutusta nykyisessä aktivoivassa mediaympäristössä esimerkkinään Euroviisut. Tuomi tarkastelee hyvin muun muassa sitä, miten yleisöä osallistetaan kansallisuuden kautta. Samalla Tuomen mukaan yleisöllä ei ole oikeaa tai puhdasta valtaa siinä määrin kuin erilaiset formaatit 
antavat ymmärtää, sillä Euroviisujen niin kuin Big Brotherin ja muiden kilpailuiden osallistujat on usein valinnut jokin ylempi taho. Kirjan viimeinen Riikka Turtiaisen ja Sari Östmanin yhteisartikkeli käsittelee internettiä, muun muassa blogeja ja keskustelupalstoja, omaehtoisen kulttuurituotannon välineenä. Artikkelin lähtökohdaksi he määrittelevät muun muassa sen, miten käyttäjien tuottamaan sisältöön tulisi suhtautua tutkimusaineistona ja minkälaisia erityisiä eettisiä kysymyksiä tutkijan on otettava huomioon tällaisen aineiston kanssa työskennellessään.

\section{KultTUURituotanNON VAiHTELEVUUS}

Vaikka kirja keskittyykin kulttuurituotannon käsittelyyn, tarjoaa se myös mielenkiintoisia huomioita kulttuurista laajemmin muun muassa kulttuurin erilaisen määritelmien kautta. Erilaiset tapausesimerkit tuovat mainiosti esille kulttuurituotannon mahdollisuudet ja alan laajuuden kirjallisuudesta museotoimintaan ja yhteisöpeleistä puukaupunginosiin. Artikkelien moninaisuus on sekä heikkous että vahvuus. Kulttuurituotannosta piirtyy osaltaan varsin laaja kuva mutta lukijalle ei muodostu kovin selkeää käsitystä siitä, mitä kulttuurituotanto on, millaiseen työhön sillä puheessa viitataan tai miten sitä esimerkiksi oppilaitoksissa voitaisiin opettaa. Samalla kuitenkin artikkelien moninaisuus - kirjallisuudesta muinaismuistoihin - pitää yllä lukijan mielenkiintoa.

Tämäntyyppiset artikkelikokoelmat tarjoavat tekijöilleen ja lukijoilleen aina kuitenkin myös monia haasteita. Artikkelien jaottelu eri osioihin tuntuu toisinaan hieman keinotekoiselta ja kirjan punainen lanka hukkuu lukijalta kerran jos toisenkin. Esimerkiksi Tuomi-Nikulan artikkeli olisi istunut paremmin osaksi paikallisuutta ja paikkaa käsittelevää osiota kuin kulttuuriperintöä käsittelevää osaa. Kulttuuriperintö nostetaan esille hänen artikkelissaan vasta viimeisellä sivulla tekstin muuten keskittyessä lähinnä muistamisen ja paikallisuuden teemoihin. Toisaalta myös El Harounyn historiallisen puukaupungin tarkastelu elinympäristönä ei tunnu aivan ongelmitta istuvan kulttuurituotannon kehyksiin. Osassa artikkeleita on myös hieman käytännöllisempiä ongelmia. Muun muassa Saarikosken artikkeli ei vastaa kunnolla esittämiinsä kysymyksiin vaan jää lähinnä pelin teossa esille nousseiden ongelmien käsittelyyn.

Myös artikkelien pituuksissa on huomattavia eroja, mikä kiinnittää lukijan huomiota. Osassa artikkeleita taas lyhyehköön tekstiin on sisällytetty niin paljon asiaa, että kokonaisuus itse artikkelin sisällä jäi lukijalle pinnalliseksi ja sirpaleiseksi. Tässä mielessä kirja ei toimine perusopintojen tasolla, mihin se tuntuu osittain tähtäävän. Kulttuurituotannosta on kuitenkin julkaistu tämän tyyppisiä kirjoja huomattavan vähän, joten tilausta tämän tyyppiselle kirjalle on olemassa. Artikkelikokoelma sisältää useita varsin mielenkiintoisia artikkeleita, ja moninaisuudessaan teos on varsin virkistävää luettavaa.

Filosofian tohtori Elina Hytönen toimii tutkijatohtorina Itä-Suomen yliopiston filosofisen tiedekunnan humanistisella osastolla. Hän on väitellyt Itä-Suomen yliopiston kulttuurintutkimuksen oppiaineesta vuonna 2010. 